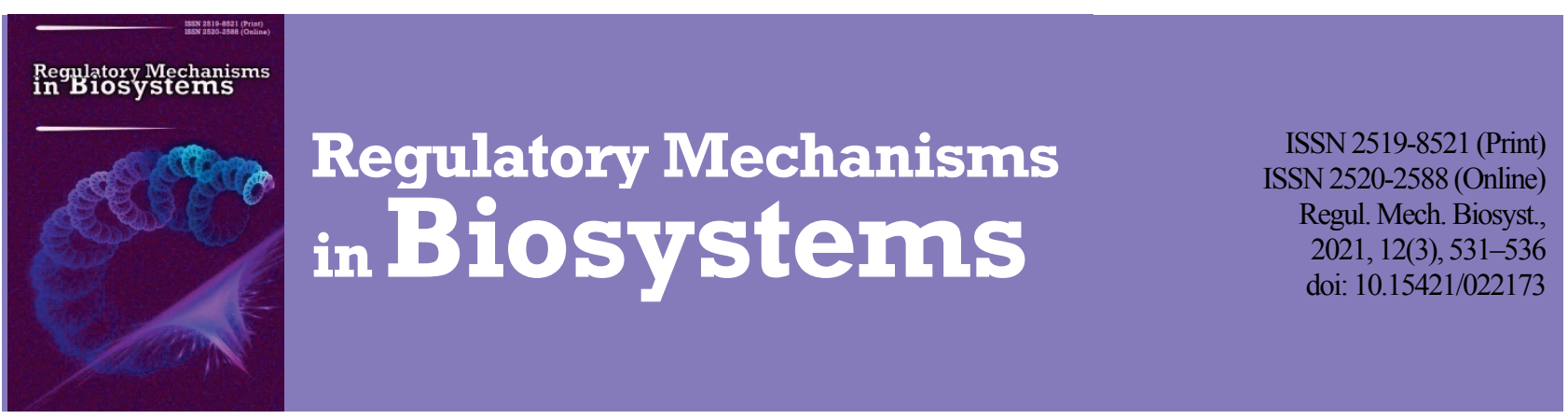

\title{
Effect of Phage SAvB14 combined with antibiotics on Staphylococcus aureus variant bovis
}

\author{
Y. V. Horiuk*, M. D. Kukhtyn**, V. V. Horiuk*, V. A. Sytnik***, O. O. Dashkovskyy**** \\ *State Agrarian and Engineering University in Podilya, Kamianets-Podilskyi, Ukraine \\ **Ternopil Ivan Puluj National Technical University, Ternopil, Ukraine \\ ***National University of Life and Environmental Sciences of Ukraine, Kyiv, Ukraine \\ ****Stepan Gzhytskyi National University of Veterinary Medicine and Biotechnologies, Lviv, Ukraine
}

Article info: Received 06.08.2021 Received in revised form 02.09.2021 Accepted 03.09.2021

State Agrarian and Engineering University in Podilya, Schevchenko st., 13 Kamianets-Podilskyi, 32300, Ukraine. Tel.: +38-097-661-79-64.

E-mail:goruky@ukr.net

Ternopil Ivan Puluj National Technical University, Ruska st., 56, Ternopil, 46001 Ukraine. Tel.: +38-097-239-20-57. E-mail:kuchtynnic@gmail.com

National University of Life and Environmental Sciences of Ukraine, Heroiv Oboronyst., 15, Kyiv, 03041, Ukraine. Tel.: +38-098-206-33-00. E-mail:vasitnik@gmail.com

Stepan Gzhytskyi National University of Veterinary Medicine and

Biotechnologies, Pekarska st.,50, Lviv, 79010, Ukraine. Tel.: + 38-097-033-2624.E-mail:dashkovs@ukr.net
Horiuk, Y. V., Kukhtyn, M. D., Horiuk, V. V., Sytnik, V. A., \& Dashkovskyy, O. O. (2021). Effect of Phage SAvB14 combined with antibiotics on Staphylococcus aureus variant bovis. Regulatory Mechanisms in Biosystems, 12(3), $531-536$. doi:10.15421/022173

Because using antimicrobial drugs leads to development of resistance among bacterial isolates, the treatment with antimicrobial drugs in human and veterinary medicine in general should be reduced. Currently, therapeutic use of bacteriophages may be an alternative or addition to the treatment of bacterial infections of animals. The article presents the results of studying the effect of bacteriophage Phage SAvB14 on microbial biofilms of Staphylococcus aureus variant bovis both alone and in complex with antibiotics. For this purpose, we used strain S. aureus var. bovis $1491 \mathrm{f}$ and bacteriophage Phage SAvB14, isolated at dairy farms. The effect of combined application of phage and antibiotics (gentamicin, tetracycline, ceftriaxone and enrofloxacin) were assessed after simultaneous and subsequent introduction of Phage SAvB14 in the dose of 105 plaque-forming units per milliliter (PFU/mL) and corresponding concentrations of antibiotics to $24 \mathrm{~h}$ biofilms. We determined that of the tested antibiotics, only gentamicin and ceftriazone exerted synergic effects in combinations with Phage SAvB14. Combination treatment using gentamicin and the phage decreased the amount of $S$. aureus in biofilm by 39.81 times compared with the phage-only treatment. Significant synergic effect was also taken by ceftriaxone - it killed 1.26 times more bacteria in combination with the phage than alone. Other antibiotics did not increase antibiotic activity of the phage. Specifically, 1.11 and 1.26 times more vital cells remained after the actions of tetracycline and enrofloxacin than after the exposure to the bacteriophage only. Therefore, the obtained results indicate that biofilm of $S$. aureus var. bovis may be eliminated using Phage SAvB14 as an individual antibacterial agent, as well as in complex with antibiotics. However, complex treatment would imply introducing the phage and then antibiotic some time later.

Keywords: biofilms; bacteriophages; antibiotics; Stapholococcus spp.; phage-antibiotic synergy; mastitis; phage therapy.

\section{Introduction}

Staphylococcus aureus is the main causative agent of mastitis in cows around the globe (Yengkho et al., 2019; Duse et al., 2021). A peculiarity of Staphylococcus mastitis is the high risk of transmitting S. aureus among the animals and the ability of the pathogen to remain in the udder of cows in the form of subclinical infection (Kirkeby et al., 2019; Peralta et al., 2020). An important factor of virulence of this pathogen is its ability of adhesion, incapsulation in the epithelial tissues and formation of biofilm which hinders the antibiotic treatment and leads to chronic infection (Kukhtyn et al., 2017; Zhao et al., 2020). Traditional treatment of Staphylococcus mastitis of cows during lactation and dry period requires using antimicrobial drugs (Bianchi et al., 2019). Efficiency of mastitis treatment of dry cows using antibiotics reached $78 \%$ (Dingwell et al., 2003), while the efficacy of those same drugs was $20-40 \%$ lower in the period of lactation (Linder et al., 2013). Despite the fact that the situation with antibioticresistance of pathogens in Ukraine is escalating, doctors cannot abandon the use of antibiotics completely (Zazharskyi et al., 2019, 2020; Horiuk et al., 2020).

Because $S$. aureus is usually highly resistant to antibiotics, being practically unbeatable, the entire antibiotic treatment is sub-inhibiting, while the pathogen becomes even more antibiotic-resistant (Yengkho et al., 2019; Peralta et al., 2020). The fact that every application of antibiotic drugs promotes resistance to bacterial isolates requires general decrease in use of antibiotic drugs in human and veterinary medicines. This emphasizes the need for alternative solutions for treating bacterial infections, including mastitis.

One of the proposed alternatives is phage therapy (Kortright et al., 2019; Berryhill et al., 2021). Bacteriophages are natural viruses that exhibit high specificity to bacterial host (Sillankorva \& Azeredo, 2014; Berryhill et al., 2021). A phage infects bacteria by injecting its genetic material through the cellular wall and the membrane, orienting the host's metabolism toward fast replication of phages. Before the final stage of the cycle of biophage replication, biophage-encoded endolysins affect the cellular wall of the bacteria from the inside, leading to release of progeny phages and elimination of the pathogen (Kim et al., 2018; Streicher, 2021). Global interest in phage therapy may be seen in the increasing amount of the recent clinical trials using peroral, intravenous and local administrations of phages (Abedon, 2020; Streicher, 2021).

One of the most serious problems of manageing microbial agents is removal of biofilms (Suresh et al., 2019). Biofilms are the commonest way of life among bacteria in the natural and artificial environments (Kumaran et al., 2018). Therefore, studies indicate that biofilms take part in at least $65 \%$ of all bacterial infections. Accordingly, efficient antibacterial therapy must be oriented at removing biofilms. Resistance mechanisms intrinsic to bacteria's way of life in biofilm vary and include interference 
of extracellular matrix with antimicrobial agents. On the one hand, the matrix creates a physical barrier to diffusion of substances, and on the other hand, chemical interactions between matrix polymers and antimicrobial substances hinder antibacterial activity (Pires et al., 2017; Gondil et al., 2020). Therefore, an important characteristic of an antimicrobial drug should be the ability to penetrate the biofilm and reach the target bacteria. Numerous studies demonstrated that bacteriophages are able to destroy biofilms in the laboratory conditions (Sillankorva \& Azeredo, 2014; Abedon, 2020). Nonetheless, natural biofilms may likely be partly resistant to phages, which would make elimination of phage-sensitive bacteria incomplete (Sillankorva \& Azeredo, 2014). Therefore, to increase the effect of phage therapy, we assessed combination effect of bacteriophages coupled with various antibiotics on staphylococcus biofilms. As expected, the advantages of such an approach were greater inhibition of growth of the bacteria and reduced bacterial ability to develop resistance against phages or antibiotics.

There are a number of studies demonstrating positive results of using staphylococcus bacteriophages and traditional antibiotics to inhibit biofilms (Kelly et al., 2012). For example, scientists (Kamal \& Dennis, 2015) reported subtherapeutic concentrations of antibiotics being favourable for phages' activity, and therefore reducing the number of bacteria. It has been reported that exposure to penicillin increased phage induction. Also, there were reports about induction of phages of Escherichia coli and Staphylococcus aureus by antibiotics of $\beta$-lactam antibiotics (Ryan et al., 2012; Chhibber et al., 2013; Chaudhry et al., 2017). Such a phenomenon was called phage-antibiotic synergy (PAS). However, such an effect was only observed after using certain combinations and it did not occur naturally.

In spite of the great variety of phages, there are still many untested phage-antibiotic combinations. Furthermore, positive effect of the treatment may depend to a high degree on the conditions of treatment, for example dosage, frequency and order of introduction, etc.

Thus, there is a need of studying various interactions between phages and antibiotics in order to develop optimized antibacterial strategies of fighting staphylococcus mastitis of cows.

The objective of this study was the influence of Phage SAvB14 on microbial biofilms of $S$. aureus var. bovis both separately and in complexes with antibiotics.

\section{Materials and methods}

For this study, we used strain $S$. aureus var. bovis $1491 \mathrm{f}$ and bacteriophage Phage SAvB14, isolated at dairy farms and deposited in the State Scientific Research Control Institute of Strains and Microorganisms (Kyiv). Isolate S. aureus var. bovis $1491 \mathrm{f}$ was the host for reproduction of the phages.

In this study, we used antibiotics of the classes that are employed in veterinary medicine most often and have different mechanisms of action toward bacterial cells: aminoglycosides (gentamicin (Basalt, Ukraine)), tetracycline (Interchemie, the Netherlands), cephalosporins (ceftriaxone (Basalt, Ukraine)) and fluoroquinolones (enrofloxacin (Basalt, Ukraine)) (Table 1). Minimum inhibiting concentrations of the selected antibiotics were the topic of our study performed earlier (Horiuk et al., 2018).

Table 1

List of antibiotics, their mechanisms of action and minimum inhibiting concentrations for Stapholococcus aureus var. bovis $1491 \mathrm{f}$

\begin{tabular}{llc}
\hline $\begin{array}{c}\text { Name of } \\
\text { antibiotic }\end{array}$ & \multicolumn{1}{c}{$\begin{array}{c}\text { Mechanism } \\
\text { of action }\end{array}$} & $\begin{array}{c}\text { Minimum inhibiting concentra- } \\
\text { tions of the antibiotics for plank- } \\
\text { ton microorganisms, } \mu \mathrm{g} / \mathrm{mL}\end{array}$ \\
\hline Gentamicin & inhibitor of protein synthesis & $12.5 \pm 1.1$ \\
Tetracycline & inhibitor of protein synthesis & $50.0 \pm 4.5$ \\
Enrofloxacin & inhibitor of DNA snthesis & $3.1 \pm 0.2$ \\
Ceftriaxone & inhibitor of synthesis of cellular wall & $22.0 \pm 1.9$ \\
\hline
\end{tabular}

For the research, we used $24 \mathrm{~h}$ biofilms of $S$. aureus var. bovis $1491 \mathrm{f}$, cultivated in disposable plastic Petri dishes. Prior to the cultivation, $5 \mathrm{~cm}^{3}$ of meat-peptone agar (Merck, USA) was added, and then $1 \mathrm{~cm}^{3}$ of $24 \mathrm{~h}$ culture of $S$. aureus was introduced in the concentration of $10^{5} \mathrm{CFU} / \mathrm{cm}^{3}$ and incubated at $37^{\circ} \mathrm{C}$ for $24 \mathrm{~h}$. For the incubation, the Petri dishes were rinsed three times with phosphate buffer to remove plankton (non-atta- ched) microorganisms, dried and then the developed biofilms were fixated using $96 \%$ ethyl alcohol for $10 \mathrm{~min}$. Then, we carried out staining with $0.1 \%$ solution of crystalline violet for $10 \mathrm{~min}$. Next, we discharged the dye and rinsed the material three times using phosphate buffer and subsequently dried it at room temperature. Then, $3.0 \mathrm{~cm}^{3}$ of $96 \%$ ethyl alcohol was added to the Petri dishes, which were left for 20-30 minutes and regularly shaken. We measured optical density of the alcohol solution using spectrophotometer technique at the wavelength of $570 \mathrm{~nm}$ (Stepanovic et al., 2000). In the experiment, we used the culture, optical density of the alcohol solution for the dye from biofilms equaled $1.78 \pm 0.07$ units, compared to $-0.12 \pm 0.01$ units (similar manipulations were done with pure meatpeptide agar without bacterial culture).

Effect of combined application of phage and antibiotic was evaluated using simultaneous and staggered introductions of antibiotics and bacteriophage. To determine the actions of antibiotics and bacteriophage Phage SAvB14 after their simultaneous exposure to rinsed $24 \mathrm{~h}$ biofilm, we introduced $1 \mathrm{~mL}$ of suspension of Phage SAvB14 with titer of $10^{5} \mathrm{PFU} / \mathrm{mL}$ and $1 \mathrm{~mL}$ of antibiotic in corresponding concentrations. The results were assessed after $24 \mathrm{~h}$. The biofilms were rinsed from the residuals of antibiotics and phages using triple sterile phosphate buffer. Then, $5 \mathrm{~cm}^{3}$ of sterile $0.5 \%$ solution of sodium chloride was added and we accurately removed the microbial biofilm from the wall and the bottom of the dish using a cotton swab. From the Petri dishes, we took $1.0 \mathrm{~cm}^{3}$ of the suspension, prepared a series of ten-fold dilutions, inoculated $1.0 \mathrm{~cm}^{3}$ of each dilution to Petri dishes, poured meat-peptone agar and carried out incubation in the temperature of $37^{\circ} \mathrm{C}$ for $24-48 \mathrm{~h}$. Control was $24 \mathrm{~h}$ biofilms that were subjected to the influence of isotonic solution of $\mathrm{NaCl}$ for $24 \mathrm{~h}$.

To determine the action of antibiotic and bacteriophage Phage SAvB14 introduced one after the other, we exposed rinsed $24 \mathrm{~h}$ biofilm to the bacteriophage $\left(10^{5} \mathrm{PFU} / \mathrm{mL}\right)$ for $12 \mathrm{~h}$, and antibiotic for the next $12 \mathrm{~h}$. The biofilms were rinsed from residuals of antibiotics and phages using sterile phosphate buffer. The amount of staphylococci was determined similarly to the experiment where the phages and antibiotic were introduced simultaneously.

To identify the action of antibiotic toward the cells of Staphylococcus in biofilm, we exposed it to certain concentrations of biocide. The biofilms were rinsed from the remains of antibiotics using sterile phosphate buffer. The number of vital cells of staphylococci in biofilm was determined in the same way as in the previous experiments. The control comprised $24 \mathrm{~h}$ biofilms exposed to $0.5 \%$ solution of $\mathrm{NaCl}$ for $24 \mathrm{~h}$.

Titer of bacteriophages was determined according to the Gracia's method (Wills et al., 2005) in liquid (mixture of bacteriophage and antibiotic) after its removal from the Petri dishes after $24 \mathrm{~h}$ influence on biofilms. The antibiotics were neutralized using the standard methods. The control was titer of bacteriophage in liquid with no antibiotics following $24 \mathrm{~h}$ action of Phage SAvB14 toward biofilm. All the studies were conducted in three replications.

The results were statistically analyzed using ANOVA, the data are presented as $\mathrm{x} \pm \mathrm{SD}$ (mean \pm standard deviation). Difference between the values in the experiment was determined using Tukey test (Tukey HSD). The difference was considered significant at $\mathrm{P}<0.05$ (taking into account Bonferroni correction).

\section{Results}

According to the results of our research and reports of other scientists, the treatment of mastitis in cows is most often performed with drugs based on aminoglycosides, tetracyclines, cephalosporins and fluoroquinolones. To perform the study, we selected four antibiotics: gentamicin, tetracycline, ceftriaxone and enrofloxacin. Those antibiotics were chosen depending on the mechanism of their action: inhibitor of protein synthesis (gentamicin, tetracycline), inhibitor of DNA synthesis (enrofloxacin) and inhibitor of synthesis of cellular wall (ceftriaxone). Previous studies revealed that 8 hours following the contact of virus and Staphylococcus, microbial cells began to undergo lysis, which decreased their number 10-fold, and $32 \mathrm{~h}$ after the phage started to contact the biofilm, no bacterial cells were generating at all (Horiuk et al., 2020). In this study, we determined the number of vital bacteria in $24 \mathrm{~h}$ of biofilm of $S$. aureus var. bovis before and after its $24 \mathrm{~h}$ exposure to bacteriophage Phage SAvB14, antibiotics 
and various combinations of them. When determining the number of S. aureus bacteria in biofilm in the conditions of its exposure to Phage SAvB14 in complex with gentamycin (Fig. 1), we determined that Phage SAvB14 did affect staphylococcus biofilm, causing 7.94 decrease in the number of vital cells $(\mathrm{P}<0.05)$, compared with the control - the action of isotonic $\mathrm{NaCl}$ solution toward the biofilm. In the same conditions, when the biofilm was exposed to gentamycin alone, the number of staphylococci decreased by 3.98 times $(\mathrm{P}<0.05)$, compared with the control. However, greatest anti-biofilm effect was observed during the action of the phage in complex with antibiotic. Simultaneous addition of antibacterial substances led to synergic interaction that expressed in 39.81 decrease in the number of bacteria $(\mathrm{P}<0.05)$, compared with Phage SAvB14 alone and 79.44 times $(\mathrm{P}<0.05)$ compared with gentamycin. Staggered influence of first the bacteriophage and then antibiotic destroyed almost 100\% of the biofilm, and decreased the number of bacteria by 25.05 times on average ( $\mathrm{P}<0.05)$, compared with simultaneous action of the phage and antibiotic.

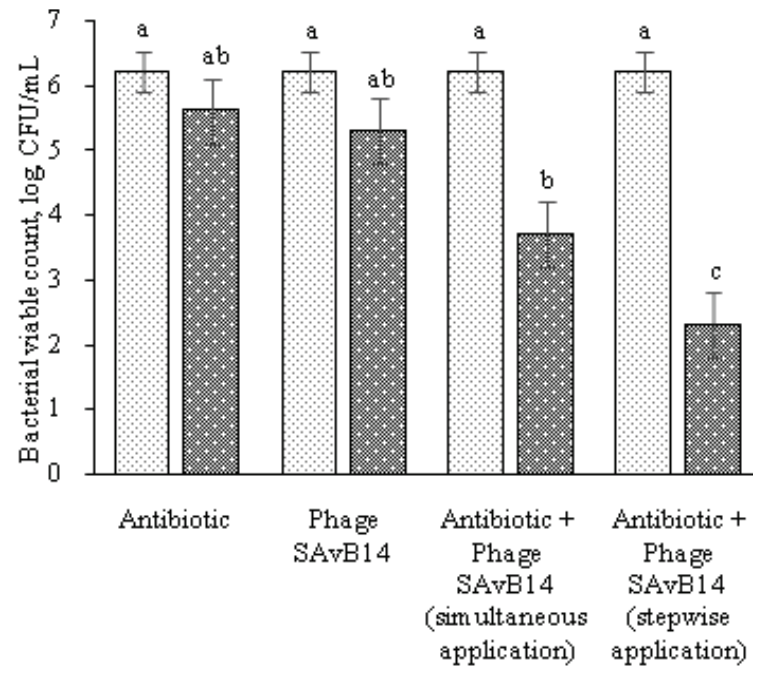

Fig. 1. Effect of Phage SAvB14 bacteriophage coupled with gentamycin on biofilm of S. aureus var. bovis ( $\mathrm{n}=3)$ : control (white column) - action of sterile isotonic $\mathrm{NaCl}$ solution toward biofilm; experiment (grey column) - effect of simultaneous action of antibiotic, antibiotic and

Phage SAvB14 bacteriophage, staggered influence of action of antibiotic and Phage SAvB14 bacteriophage, values in columns

(letters $a, b, c$ ) may differ by $\mathrm{P}<0.05$ according to Tukey test

The results of identifying the effect of Phage SAvB14 bacteriophage coupled with tetracycline on Staphylococcus biofilms (Fig. 2) revealed that bactericidal interaction with tetracycline was weaker, compared with gentamycin. Therefore, simultaneous introduction of the phage and tetracycline caused no synergic effect on biofilms of staphylococci, the number of which was the same as after exposure to bacteriophage only. At the same time, staggered introduction of phage and antibiotic led to more notable bactericidal effect - the number of bacteria was 6.31 times $(\mathrm{P}<$ $0.05)$ lower than after the simultaneous use.

Representative of fluoroquinolones - enrofloxacin also caused no increase in the synergic antimicrobial effect when coupled with Phage SAvB14 in the conditions of their simultaneous introduction (Fig. 3), the number of cells in biofilm was the same as after exposure to phage or antibiotic. However, after staggered treatment with phage and enfloxacin, we observed higher mortality among staphylococci cells, their number decreased by 50.12 on average $(\mathrm{P}<0.05)$, equaling $3.7 \log \mathrm{CFU} / \mathrm{mL}$ of water sample.

Similar tendency was also seen when studying interaction between Phage SAvB14 and ceftriaxone (Fig. 4). The data presented in Figure 4 suggests that staggered introduction of the phage and ceftriaxone produced significant decrease in cells of staphylococci in the biofilm down to $2.7 \log \mathrm{CFU} / \mathrm{mL}$, which was on average 316.34 times $(\mathrm{P}<0.05)$ less than such caused by simultaneous introduction of the phage coupled with antibiotic. Other variants of eliminating bacteria in biofilm were less effective.
Titer of Phage SAvB14 bacteriophage underwent changes after being used with different combinations of antibiotics (Fig. 5). In particular, after staggered treatment with bacteriophages and antibiotics, titer of phages was on average 8.45 times $(\mathrm{P}<0.05)$ lower than after simultaneous introduction, equaling 7.1-7.7 $\log \mathrm{PFU} / \mathrm{mL}$ (experiment 2). At the same time, the lowest titer was seen after simultaneous use of the phage with gentamycin - $\log 5.4 \mathrm{PFU} / \mathrm{mL}$ (experiment 1). After simultaneous applications of the phage with other antibiotics (tetracycline, enrofloxacin and ceftriaxone), it was 7.91-398.10 times higher $(\mathrm{P}<0.05)$, compared with gentamycin.

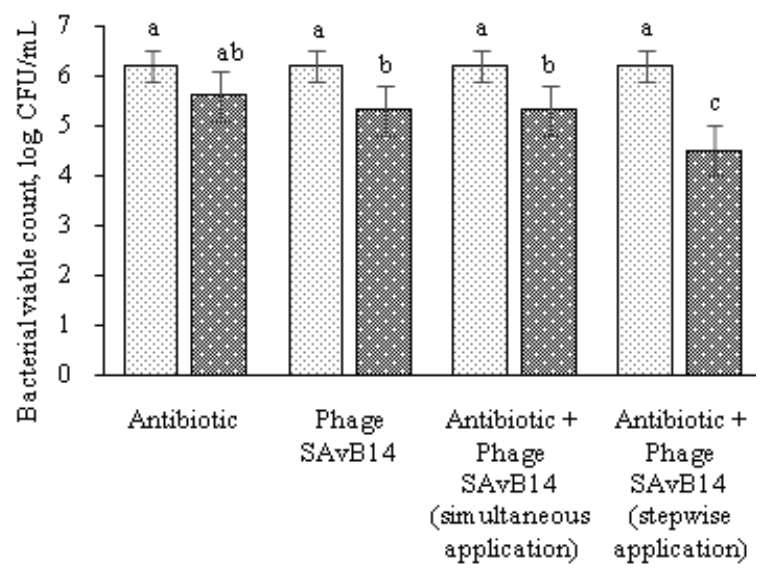

Fig. 2. Influence of Phage SAvB14 bacteriophage on biofilms of $S$. aureus var. bovis in complex with tetracycline $(\mathrm{n}=3)$ : see Fig. 1

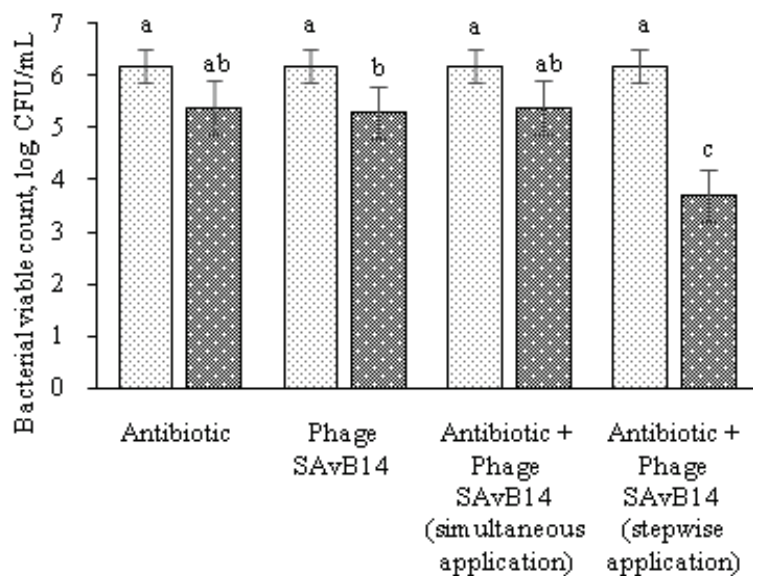

Fig. 3. Effect of Phage SAvB14 bacteriophage on biofilm of $S$. aureus var. bovis in complex with enrofloxacin $(\mathrm{n}=3)$ : see Fig. 1

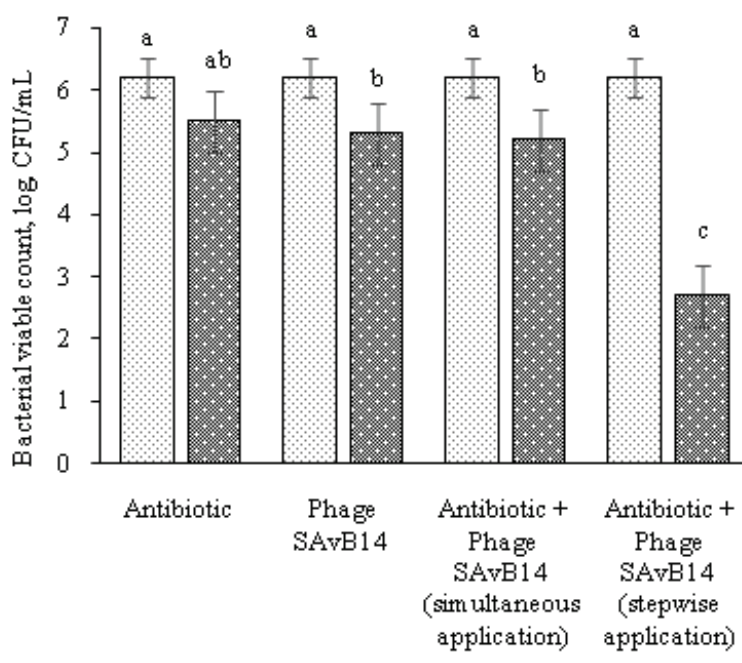

Fig. 4. Effect of Phage SAvB14 bacteriophage on biofilms of $S$. aureus var. bovis in complex with ceftriaxone $(\mathrm{n}=3)$ : see Fig. 1 


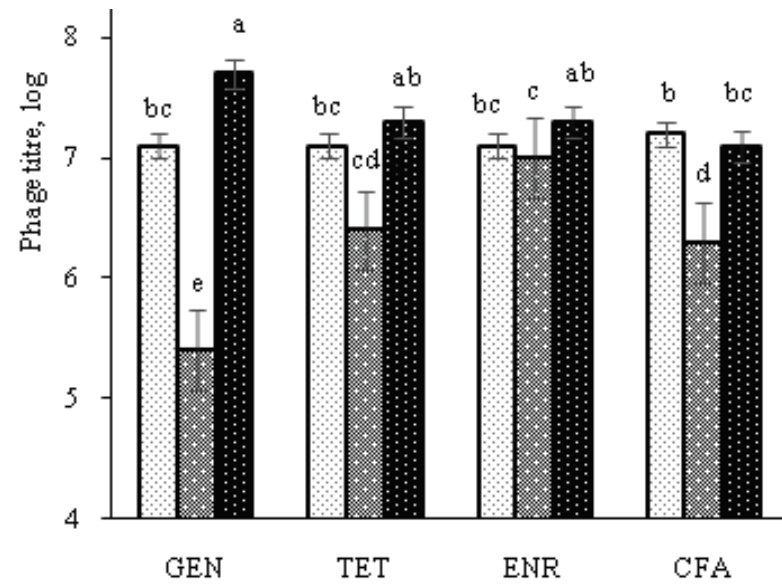

Fig. 5. Titer of bacteriophage Phage SAvB14 in the conditions of action towards Stapholococcus aureus var. bovis separately and in complex with antibiotics (GEN - gentamycin, TET - tetracycline, ENR - enrofloxacin, $\mathrm{CFA}$ - ceftriaxone, $\mathrm{n}=3$ ): control (white column) - titer of bacteriophage after $24 \mathrm{~h}$ of action towards biofilm, experiment 1 (grey column) - titer of bacteriophage after $24 \mathrm{~h}$ influence on biofilm caused by simultaneous application of GEN, TET, ENR and CFA, experiment 2 (black column) titer of bacteriophage after $24 \mathrm{~h}$ influence caused by staggered introduction of GEN, TET, ENR and CFA, values in columns (letters $a, b, c, d, e$ ) differ by $\mathrm{P}<0.05$ according to Tukey test

\section{Discussion}

Bacterial cells are most often structured in multi-cellular communities biofilms - where they can resist the negative effects of the environment (Dingwell et al., 2003; Pires et al., 2017). Indeed, one of the most difficult current tasks in combating bacterial infections around the globe is destroying biofilms. Development of biofilms of $S$. aureus var. bovis during mastitis of cows is first of all associated with decrease in sensitivity of the pathogen to antimicrobial drugs, which may be explained by limiting of diffusion of active agents through matrix of biofilm and decrease in metabolic activity of bacteria in its composition (Dingwell et al., 2003). Against such a background and increase in resistance to antibiotics, the interest in use of bacteriophages as antibacterial agents has returned (Kortright et al., 2019; Abedon, 2020; Streicher, 2021). One of the properties of phages is their ability to permeate into the deep layers of biofilms and destroy target bacteria (Abedon, 2020). However, there are a number of restrictions regarding their use, one of which being the ability of bacteria to become resistant to phages (Kamal \& Dennis, 2015). Therefore, researchers have proposed combination therapy as a mean of controlling the resistance of pathogens to both phages and antibiotics. In a perfect scenario, phageantibiotic combination should be developed in such a way that resistance to one agent would increase susceptibility to the other. However, the synergic antimicrobial effect of phage-antibiotic complex depends on many factors, specifically concentration, lytic cycle of bacteriophage, mechanism of antibiotic's action toward bacterial cell, etc. (Ryan et al., 2012; Chaudhry et al., 2017).

Earlier described Phage SAvB14 (Horiuk et al., 2020), as a specific staphylococcus bacteriophage, is efficient in destroying biofilms developed by $S$. aureus var. bovis in cows' mastitis. In this study, we focused on synergic activity with various antibiotics against $24 \mathrm{~h}$ biofilms of $S$. aureus var. bovis.

The results described in this study indicate that Phage SAvB14 phage was more efficient against $S$. aureus var. bovis in the formed biofilm than antibiotics used in the experiment. The phage decimated 1.99 times $(\mathrm{P}<$ $0.05)$ more bacteria that gentamycin, 1.97 times $(\mathrm{P}<0.05)$ more than tetracycline, 1.25 times $(\mathrm{P}<0.05)$ more than enrofloxacin and 1.58 times $(\mathrm{P}<0.05)$ more than ceftriaxone.

Complex simultaneous introduction of phage and antibiotic also decreased the number of vital bacteria. However, efficacy of simultaneous treatment with antibiotic-phage complex was lower than use of phage alone. Only two of the studied antibiotics (gentamycin and ceftriaxone) exerted synergic effect in combination with Phage SAvB14, whereas their combined use decreased the number of $S$. aureus in biofilm by 39.81 times $(\mathrm{P}<0.05)$ compared with the phage-only treatment. Significant synergic effect was also exhibited by ceftriaxone - simultaneously introduced with the phage it killed 1.26 times $(\mathrm{P}<0.05)$ more bacteria than the phage only. Other antibiotics did not increase the anti-biofilm action of the phage. In particular, tetracycline and enrofloxacin left 1.11 and 1.26 times $(\mathrm{P}<0.05)$ more vital cells than the action of bacteriophage alone.

Our studies also found that the lowest titer of bacteriophage (log 5.4 7.0 PFU/mL) was observed after simultaneous use of phage and antibiotic. Therefore, antibiotics also took antagonistic effect on the action of the phages. This phenomenon was explained by researchers (Dickey \& Perrot, 2019), who reported that proteins are some of the structural components of virions, and after using antibiotics, one of the mechanisms may be inhibition of protein and DNA syntheses, which may further influence the development of new phage virions.

Exposure of biofilm to phages before introduction of antibiotics allows phages to quickly reproduce in the bacterially dense environment of biofilm, causing high density of phages and respectively damage to the matrix (Kasman et al., 2002; Chaudhry et al., 2017). Addition of antibiotics to such a system leads to fast decrease in the number of bacteria because of deeper penetration of antimicrobial substances. However, when biofilms are first exposed to actions of antibiotics and then phages, the population of bacteria that the phage could infect decreases, which may negatively affect kinetics of bacteriophage reproduction and ultimately the efficiency of phage therapy (Horiuk et al., 2020; Morrisette et al., 2020). Research has (Wang et al., 2020) experimentally confirmed that staggered introduction of Sb-1, flucloxacillin, cefazolin or fosfomycin improved antibiotic activity toward biofilms in four of six methicillin-sensitive $S$. aureus, whereas simultaneous influence demonstrated similar or less synergy. Our studies correlate with the earlier published data (Wang et al., 2020), when staggered introduction of phage and antibiotic caused 97.5$100.0 \%$ destruction of biofilm.

Mechanism of antibiotics' action toward microbial cells may also affect phage-antibiotic interaction during the destruction of biofilm. Therefore, we selected antibiotics with various means of action. According to the results of the studies, the greatest synergism of interaction with Phage SAvB14 phage was exerted by gentamycin (Fig. 1). Aminoglycosides are inhibitors of protein synthesis, which would most likely inhibit the production of phages. However, the study of interaction with this class of antibiotics revealed that phages have a mechanism that allows avoidance of antibiotic inhibition of ribosome and provide synthesis of phage proteins (Conlter et al., 2014). On the other hand, bactericidal substances enhance cellular respiration with following stimulation of hydroxyl radicals that cause death of cells (Kohanski et al., 2007). Because the replication of phages is believed to depend on metabolically active bacteria, increase in cellular respiration may stimulate indirect phage infection (Abedon, 2020). Furthermore, this phenomenon may be explained by the fact that aminoglycosides may form populations of bacteria with strong aggregation phenotype, which have increased ability to develop biofilms. However, these populations of microorganisms are more sensitive to influence of bacteriophages than their parental strain (Kirby, 2012).

A somewhat lower level of interaction was exhibited by ceftriaxone (Fig. 4). It increased the impact of the phage on cells in biofilm by 1.261.71 times $(\mathrm{P}<0.05)$. This may be explained by the fact that cephalosporins are inhibitors of the cellular wall, which increase filamentation of cells, and therefore provoke production of higher number of phage particles (Kim et al., 2018). It is also possible that combination treatment using phage enzymes that damage the integrity of bacterial membrane in complex with action of antibiotic may significantly improve lysis of cell.

Other antibiotics taken into the study displayed low synergic antibacterial effect in combinations with bacteriophage Phage SAvB14. The reason for this may be the antagonistic mechanism of action. For example, an antibiotic obstructs the replication of bacterial DNA, or because antibiotic destroys host bacteria that are necessary for spreading phage infection. (Wills et al., 2005; Chhibber et al., 2013; Akturk et al., 2019).

Therefore, the results of the study reveal that the greatest synergic effect of interaction between Phage SAvB14 and the tested antibiotics was 
observed during their staggered introduction (first bacteriophage, then antibiotic). However, none of the combinations of phage and antibiotic led to complete elimination of staphylococcus cells in biofilm, even despite significant synergy of phage with such antibiotics as gentamycin and ceftriaxone. This indicates the role of biofilm in protection of bacteria from antibiotics and formation of persistence cells.

\section{Conclusion}

The study revealed that the greatest synergic effect of interaction between Phage SAvB14 phage and antibiotics was seen after their staggered application (first bacteriophage and then antibiotic). Simultaneous introduction of Phage SAvB14 and gentamycin caused 39.8-fold decrease ( $\mathrm{P}<$ 0.05 ) in the number of vital staphylococci in biofilm, while no cells were being produced after staggered treatment. Influence of Phage SAvB14 bacteriophage in complex with tetracycline used simultaneously caused no synergic effect on staphylococci in biofilm, whereas staggered introduction of Phage SAvB14 and antibiotic took notable bactericidal effect the number of bacteria was 6.31 times $(\mathrm{P}<0.05)$ lower than after simultaneous use.

Enfloxacin led to no increase in synergic antimicrobial effect during interaction with Phage SAvB14 in simultaneous treatment, although staggered introduction of phage and enfloxacin decreased the number of staphylococci by 50.12 times $(\mathrm{P}<0.05)$ on average. A similar tendency was seen during interaction between Phage SAvB14 and ceftriaxone: staggered treatment decreased the number of staphylococcus cells in biofilm to $2.7 \log \mathrm{CFU} / \mathrm{mL}$ of water sample, which was on average 316.34 times $(\mathrm{P}<0.05)$ lower than after simultaneous introduction of phage and antibiotic.

Titer of Phage SAvB14 bacteriophage also underwent changes in the case of its application with various combinations of antibiotics. Particularly, after staggered treatment with bacteriophages and antibiotics, phage titer was on average 8.45 times $(\mathrm{P}<0.05)$ higher than after simultaneous introduction. At the same time, the lowest titer was observed after simultaneous use of phage and gentamycin $(\log 5.4 \mathrm{PFU} / \mathrm{mL})$. After influence of other antibiotics: tetracycline, ceftriaxone and enrofloxacin, it was higher by 7.91-398.10 times $(\mathrm{P}<0.05)$.

The results we obtained suggest that to destroy biofilms of $S$. aureus var. bovis, one may use Phage SAvB14 as a separate antibacterial agent, as well as in complex with antibiotics. However, using the phage in complex with antibiotics it would be expedient to introduce the phage first and then the antibiotic after a certain time.

The authors declare no conflict of interest.

\section{References}

Abedon, S. T. (2020). Phage-phage, phage-bacteria, and phage-environment communication. In: Witzany, G. (Ed.). Biocommunication of phages. Springer Nature Switzerland, Cham.

Akturk, E., Oliveira, H., Santos, S. B., Costa, S., Kuyumcu, S., Melo, L. D., \& Azeredo, J. (2019). Synergistic action of phage and antibiotics: Parameters to enhance the killing efficacy against mono and dual-species biofilms. Antibiotics, 8(3), 103.

Berryhill, B. A., Huseby, D. L., McCall, I. C., Hughes, D., \& Levin, B. R. (2021). Evaluating the potential efficacy and limitations of a phage for joint antibiotic and phage therapy of Staphylococcus aureus infections. Proceedings of the National Academy of Sciences, 118(10), e2008007118.

Bianchi, R. M., Schwertz, C. I., De Cecco, B. S., Panziera, W., De Lorenzo, C., Heck, L. C., \& Driemeier, D. (2019). Pathological and microbiological characterization of mastitis in dairy cows. Tropical Animal Health and Production, 51(7), 2057-2066.

Chaudhry, W. N., Concepcion-Acevedo, J., Park, T., Andleeb, S., Bull, J. J., \& Levin, B. R. (2017). Synergy and order effects of antibiotics and phages in killing Pseudomonas aeruginosa biofilms. PLoS One, 12(1), e0168615.

Chhibber, S., Kaur, T., \& Kaur, S. (2013). Co-therapy using lytic bacteriophage and linezolid: Effective treatment in eliminating methicillin resistant Staphylococcus aureus (MRSA) from diabetic foot infections. PLoS One, 8(2), e56022.

Coulter, L. B., McLean, R. J., Rohde, R. E., \& Aron, G. M. (2014). Effect of bacteriophage infection in combination with tobramycin on the emergence of resistance in Escherichia coli and Pseudomonas aeruginosa biofilms. Viruses, 6(10), 3778-3786.
Dickey, J., \& Perrot, V. (2019). Adjunct phage treatment enhances the effectiveness of low antibiotic concentration against Staphylococcus aureus biofilms in vitro. PLoS One, 14(1), e0209390.

Dingwell, R. T., Leslie, K. E., Duffield, T. F., Schukken, Y. H., DesCoteaux, L., Keefe, G. P., \& Bagg, R. (2003). Efficacy of intramammary tilmicosin and risk factors for cure of Staphylococcus aureus infection in the dry period. Journal of Dairy Science, 86, 159-168.

Duse, A., Persson-Waller, K., \& Pedersen, K. (2021). Microbial aetiology, antibiotic susceptibility and pathogen-specific risk factors for udder pathogens from clinical mastitis in dairy cows. Animals, 11(7), 2113.

Gondil, V. S., Harjai, K., \& Chhibber, S. (2020). Endolysins as emerging alternative therapeutic agents to counter drug-resistant infections. International Joumal of Antimicrobial Agents, 55(2), 105844.

Horiuk, Y. V., Havrylianchyk, R. Y., Horiuk, V. V., Kukhtyn, M. D., Stravskyy, Y.S., \& Fotina, H. A. (2018). Comparison of the minimum bactericidal concentration of antibiotics on planktonic and biofilm forms of Staphylococcus aureus: Mastitis causative agents. Research Journal of Pharmaceutical, Biological and Chemical Sciences, 9(6), 616-622.

Horiuk, Y., Kukhtyn, M., Horiuk, V., Kernychnyi, S., \& Tarasenko, L. (2020). Characteristics of bacteriophages of the Staphylococcus aureus variant bovis. Veterinami Medicina, 65, 421-426.

Kamal, F., \& Dennis, J. J. (2015). Burkholderia cepacia complex phage-antibiotic synergy (PAS): Antibiotics stimulate lytic phage activity. Applied and Environmental Microbiology, 81(3), 1132-1138.

Kasman, L. M., Kasman, A., Westwater, C., Dolan, J., Schmidt, M. G., \& Norris, J. S. (2002). Overcoming the phage replication threshold: A mathematical model with implications for phage therapy. Joumal of Virology, 76(11), 5557-5564.

Kelly, D., McAuliffe, O., Ross, R. P., \& Coffey, A. (2012). Prevention of Staphylococcus aureus biofilm formation and reduction in established biofilm density using a combination of phage $\mathrm{K}$ and modified derivatives. Letters in Applied Microbiology, 54(4), 286-291.

Kim, M., Jo, Y., Hwang, Y. J., Hong, H. W., Hong, S. S., Park, K., \& Myung, H. (2018). Phage-antibiotic synergy via delayed lysis. Applied and Environmental Microbiology, 84(22), e02085-18.

Kirby, A. E. (2012). Synergistic action of gentamicin and bacteriophage in a continuous culture population of Staphylococcus aureus. PLoS One, 7(11), e51017.

Kirkeby, C., Zervens, L., Toft, N., Schwarz, D., Farre, M., Hechinger, S., \& Halasa, T. (2019). Transmission dynamics of Staphylococcus aureus within two Danish dairy cattle herds. International Journal of Dairy Science, 102(2), 1428-1442.

Kohanski, M. A., Dwyer, D. J., Hayete, B., Lawrence, C. A., \& Collins, J. J. (2007). A common mechanism of cellular death induced by bactericidal antibiotics. Cell, 130(5), 797-810.

Kortright, K. E., Chan, B. K., Koff, J. L., \& Turner, P. E. (2019). Phage therapy: A renewed approach to combat antibiotic-resistant bacteria. Cell Host and Microbe, 25, 219-232.

Kukhtyn, M., Berhilevych, O., Kravcheniuk, K., Shynkaruk, O., Horiuk, Y., \& Semaniuk, N. (2017). Formation of biofilms on dairy equipment and the influence of disinfectants on them. Eastern-European Journal of Enterprise Technologies, 89, 26-33.

Kumaran, D., Taha, M., Yi, Q., Ramirez-Arcos, S., Diallo, J. S., Carli, A., \& Abdelbary, H. (2018). Does treatment order matter? Investigating the ability of bacteriophage to augment antibiotic activity against Staphylococcus aureus biofilms. Frontiers in Microbiology, 9, 127.

Linder, M., Paduch, J. H., Grieger, A. S., Mansion-de Vries, E., Knorr, N., Zinke, C., \& Krömker, V. (2013). Heilungsraten chronischer subklinischer Staphylococcus aureus - Mastitiden nach antibiotischer Therapie bei laktierenden Milchkühen. Cure rates of chronic subclinical Staphylococcus aureus mastitis in lactating dairy cows after antibiotic therapy. Berliner und Münchener Tierärztliche Wochenschrift, 6, 291-296.

Morrisette, T., Kebriaei, R., Lev, K. L., Morales, S., \& Rybak, M. J. (2020). Bacteriophage therapeutics: A primer for clinicians on phage-antibiotic combinations. Pharmacotherapy, 40(2), 153-168.

Peralta, O. A., Carrasco, C., Vieytes, C., Tamayo, M. J., Muñoz, I., Sepulveda, S., \& Torres, C. G. (2020). Safety and efficacy of a mesenchymal stem cell intramammary therapy in dairy cows with experimentally induced Staphylococcus aureus clinical mastitis. Scientific Reports, 10(1), 2843.

Pires, D. P., Melo, L. D., Boas, D. V., Sillankorva, S., \& Azeredo, J. (2017). Phage therapy as an alternative or complementary strategy to prevent and control biofilm-related infections. Current Opinion in Microbiology, 39, 48-56.

Ryan, E. M., Alkawareek, M. Y., Donnelly, R. F., \& Gilmore, B. F. (2012). Synergistic phage-antibiotic combinations for the control of Escherichia coli biofilms in vitro. FEMS Immunology and Medical Microbiology, 65(2), 395-398.

Sillankorva, S., \& Azeredo J. (2014). Bacteriophage attack as an anti-biofilm strategy. In: Donelli, G. (Ed.). Microbial biofilms. Methods in molecular biology (methods and protocols). Humana Press, New York.

Stepanović, S., Vuković, D., Dakić, I., Savić, B., \& Švabić-Vlahović, M. (2000). A modified microtiter-plate test for quantification of staphylococcal biofilm formation. Journal of Microbiological Methods, 40(2), 175-179. 
Streicher, L. M. (2021). Exploring the future of infectious disease treatment in a postantibiotic era: A comparative review of alternative therapeutics. Journal of Global Antimicrobial Resistance, 24, 285-295.

Suresh, M. K., Biswas, R., \& Biswas, L. (2019). An update on recent developments in the prevention and treatment of Staphylococcus aureus biofilms. International Journal of Medical Microbiology, 309(1), 1-12.

Wang, L., Tkhilaishvili, T., Trampuz, A., \& Moreno, M. G. (2020). Evaluation of staphylococcal bacteriophage $\mathrm{Sb}-1$ as an adjunctive agent to antibiotics against rifampin-resistant Staphylococcus aureus biofilms. Frontiers in Microbiology, $11,602057$.

Wills, Q. F., Kerrigan, C., \& Soothill, J. S. (2005). Experimental bacteriophage protection against Staphylococcus aureus abscesses in a rabbit model. Antimicrobial Agents and Chemotherapy, 49(3), 1220-1221.
Yengkho, R., Gupta, M., Lokesha, E., Handique, B., \& Singh, L. K. (2019). Bovine mastitis and its treatment strategies. Joumal of Veterinary Science and Technology, 7(3), 11-16

Zazharskyi, V. V., Davydenko, P. O., Kulishenko, O. M., Borovik, I. V., \& Brygadyrenko, V. V. (2019). Antimicrobial activity of 50 plant extracts. Biosystems Diversity, 27(2), 163-169.

Zazharskyi, V. V., Davydenko, P. O., Kulishenko, O. M., Borovik, I. V., Zazharska, N. M., \& Brygadyrenko, V. V. (2020). Antibacterial and fungicidal activities of ethanol extracts of 38 species of plants. Biosystems Diversity, 28(3), 281-289.

Zhao, X., Yuan, X., Hu, M., Zhang, Y., Li, L., Zhang, Q., \& Liu, Y. (2020). Prevalence and characterization of Staphylococcus aureus and methicillin-resistant Staphylococcus aureus isolated from bulk tank milk in Shandong dairy farms. Food Control, 125, 107836 